УДК 78.034.784.1+78.01

DOI: https://doi.org/10.33643/kmus.2019.58.12

Марія Марченко,

здобувач кафедри історії та теорії культури Національної музичної академї України ім. П. І. Чайковського https://orcid.org/0000-0002-5814-7422 Mari_marchenko@icloud.com

Mariia Marchenko, Applicant at the Department of Theory and History of Culture, Ukrainian National Tchaikovsky Academy of Music https://orcid.org/0000-0002-5814-7422 Mari_marchenko@icloud.com

\title{
ОСМИСЛЕННЯ ЗВУКОВОГО ОБРАЗУ ПАРТЕСНОГО ТВОРУ ЧЕРЕЗ ЗВ'ЯЗОК МУЗИЧНОГО ТА РИТОРИЧНОГО МИСТЕЦТВ У XVII СТОЛІТТІ
}

Статтю присвячено виконавському аспекту української барокової музики, а саме: осмиленню звукового образу партесного твору через зв'язок музичного та риторичного мистецтва в зазначений час. Даний феномен національної культури $\epsilon$ предметом професійного інтересу науковців, починаючи 3 другої третини XX століття в теоретичному, історичному, текстологічному, джерелознавчому та інших аспектах. Однак, під час практичної роботи з твором даної епохи стає очевидною наявність суттєвої кількості «чорних плям» відносно інтерпретації та художнього осмислення твору. Отже, мета дослідження - осмислити характер звукового образу партесного твору через специфіку синтезу музичного та риторичного мистецтв в українській бароковій музиці. У дослідженні проаналізовано елементи синтаксису риторичного й музичного мистецтв в художньому тексті української барокової музики, прослідковано форми їхнього синтезу та впливу на характер звукового образу. Методологія дослідження полягає в застосуванні методів аналізу та синтезу, порівняльного методу та підходів семіотики й герменевтики. Наукова новизна дослідження полягає в поглибленні наукових знань щодо особливостей інтерпретації партесного твору, відкритті нових орієнтирів для досягнення достовірності звучання твору українського бароко. Висновки. Українській бароковій музиці притаманні специфічні форми взаємодії риторичного та музичного мистецтва як на рівні окремих епізодів, так і на рівні архітектоніки цілого твору, що виявляються в «апріорній», визначальній ролі слова, декламаційності, емоційності вислову, ораторській інтонації, прагненні взаємодії зі слухачем, 
просторовості, «відкритості», символічності, діалогічності (принцип «питання-відповідь»), ідентифікація та реалізація яких наближає виконавця до втілення історично-достовірного звукового образу.

Ключові слова: українська барокова музика, риторика, питаннявідповідь, звуковий образ, партес.

Marchenko Mariia. Understanding the nature of the sound image of the party work due to the connection of music and rhetoric in Ukrainian Baroque music. The question of synergy and synthesis in the Baroque cultural paradigm of musical and rhetorical art is a kind of axiom. One of the most famous scholars and authenticators N. Harnoncourt offers to use the term «rhetorical music» instead of «old» music. In the segment of Ukrainian baroque art, this integrative connection has its own specific features. The phenomenon of Ukrainian Baroque art is the subject of professional curiosity of scholars from the third part of the XX century in theoretical, historical, textual, sources, etc. sections. The question is - how we should perform «partes» compositions, on which stylistic canons to rely on. This question arise in most of professional vocalists and choirs, and this is why, for the first time, the performance aspect of this art is the subject of the research. In the context of receiving the Ukrainian Orthodox Church tomos, the issue of achieving historical authenticity in the performance of the first professional works of the cult musical art of Ukraine was updated with new force. In this article, we localize our attention precisely on the question of the character of the sound image of the party work, which is the result of the synthesis and interpenetration of rhetorical and musical arts in the 17th century. The purpose of the article is to understand the nature of the sound image of the partes pieces due to the specifics of the synthesis of musical and rhetorical arts in Ukrainian Baroque music. Methodology of research. In this article, we analyze elements of the syntax of rhetorical and musical arts in the artistic text of Ukrainian Baroque music, tracking the forms of their synthesis and the effect on the nature of the sound image. The methodology of the research is to apply methods of analysis and synthesis, the comparative method and approaches of semiotics and hermeneutics. The scientific novelty of the research is to deepen scientific knowledge in relation to the peculiarities of the interpretation of the partes works, the discovery of new landmarks for the achievement of the authenticity of the sound of the work of the Ukrainian Baroque. Conclusions. In Ukrainian Baroque music, we observe specific forms of interaction between rhetorical and musical art both at the level of local episodes and at the level of the architectonics of the whole work, which are manifested in the «a priori», the determining role of the word, declamatory, emotional expression, oratory intonation, tendency to interact with the listener, 
spatial, «openness», symbolism dialogicity (principle of question-answer). Identification and implementation of these elements brings closer the performer to the realization true sound image.

Key words: Ukrainian baroque music; rhetoric; question-answer; sound image; partes.

\section{Марченко Мария. Осмысление звукового образа партесного} произведения через связь музыки и риторики в XVII веке. Вопрос синергии и синтеза в барочной культурной парадигме музыкального и риторического искусства является своего рода аксиомой. Один из найболее известных ученых и исполнителей-автентистов Н. Арнонкур предлагает пользоваться термином «риторическая музыка» вместо «старинная» музыка. В сегменте украинского барочного искусства такого рода интегративная связь имеет свои специфические особенности. Феноменукраинского барочного искусства является предметом профессионального интереса ученых, начиная со второй трети XX века в теоретическом, историческом, текстологическом и других аспектах. Вопросы о том, как исполнять партесные произведения, на какие стилевые каноны опираться в интерпретации возникают у большинства профессиональных вокалистов и хормейстеров, поэтому впервые именно исполнительский аспект партесного музицирования является предметом исследования. В контексте получения украинской православной церковью томоса, вопрос достижения исторической достоверности в исполнении первых профессиональных произведений культового музыкального искусства Украины актуализировался с новой силой. В данной статье внимание сосредоточено на характере звукового «образа» партесного произведения, являющегося результатом синтеза и взаимопроникновения риторического и музыкального искусств в XVII веке. Таким образом, цель исследования - осмыслить характер звукового образа партесного произведения сквозь призму специфики синтеза музыкального и риторического искусства в украинской барочной музыке. Методология исследования. В данной статье мы анализируем элементы синтаксиса риторического и музыкального искусств в художественном тексте украинской барочной музыки, отслеживая формы их синтеза и влияния на характер звукового образа. Методология исследования заключается в применении методов анализа и синтеза, сравнительного метода и подходов семиотики и герменевтики. Научная новизна исследования заключается в углублении научных знаний относительно особенностей интерпретации партесного произведения, открытии новых ориентиров для достижения достоверности звучания произведения украинского барокко. Выводы. В 
украинской барочной музыке мы наблюдаем специфические формы взаимодействия риторического и музыкального искусства как на уровне отдельных эпизодов, так и на уровне архитектоники целого произведения, проявленные в «априорной», определяющей роли слова, декламационности, эмоциональности высказывания, ораторской интонации, тяготении к взаимодействию со слушателем, пространственности, «открытости», символичности, диалогичности (принцип вопрос-ответ), идентификация и реализация которых приближает исполнителя к воплощению исторически достоверного звукового образа.

Ключевые слова: украинская барочная музыка; риторика; вопросответ; звуковой образ; партес.

Актуальність теми дослідження. Феномен українського барокового мистецтва $\epsilon$ предметом професійної зацікавленості науковців починаючи 3 другої третини ХX століття в теоретичному, історичному, текстологічному, джерелознавчому та інших аспектах. Питання щодо того, як саме виконувати партесні твори, на які стильові канони спиратись виникають у більшості професійних вокалістів і хормейстерів, тому вперше саме виконавський аспект даного мистецтва $\epsilon$ предметом дослідження. У контексті отримання українською православною церквою томосу питання досягнення історичної достовірності у виконанні перших професійних творів культового музичного мистецтва України актуалізувалося 3 новою силою. У даній статті увагу зосереджено саме на питанні характеру «звукового образу» партесного твору, що $\epsilon$ результатом синтезу та взаємопроникнення риторичного й музичного мистецтв у XVII столітті.

Аналіз останніх досліджень $\boldsymbol{i}$ публікацій. В останні роки дослідженням українського сегменту української барокової музики займались Н. О. Герасимова-Персидська [2-4], С. Ігнатенко [7], I. Кузьмінський [8], Ю. Медведик [9], О. Шуміліна [14], Ю. Ясиновський. Науковий інтерес був спрямований як на дослідження різних аспектів художнього тексту творів українського бароко, так і на кодикологічну діяльність, розшифровку рукописного матеріалу та зведення партій.

Mema cmammi - осмислити характер звукового образу партесного твору через специфіку синтезу музичного й риторичного мистецтв в українській бароковій музиці.

Питання синергії та синтезу в бароковій культурній парадигмі музичного й риторичного мистецтв $є$ свого роду аксіомою. Один із найвідоміших учених i виконавців-автентистів Н. Арнонкур пропонує користуватись терміном «риторична музика» замість «старовинна музика». 
У сегменті українського барокового мистецтва даний інтегративний зв'язок має свої специфічні особливості. На терени Русі мистецтво красномовства приходить разом із прийняттям християнства, збагачене потужною античною та візантійською традиціями, а в XVII столітті починається етап розквіту риторики на теренах України. Курс риторики був важливою складовою освітнього процесу Києво-Могилянської академії в складі «ординарних» (обов'язкових) класів: збереглося близько ста двадцяти семи курсів риторики, що походять зі славетного навчального закладу.

У викладанні риторичних класів педагоги КМА (одним з яких був Ф. Прокопович) спиралися на античні риторичні традиції. Наприклад, відповідно до концепції Ф. Прокоповича, ораторська майстерність полягає не тільки в мистецтві переконувати й доводити, а найперше - у сугестивній дії, мистецтві викликати почуття, змінювати світогляд i приносити «естетичну» насолоду й радість, що виявляє певний паралелізм iз роллю музичного мистецтва в зазначений час. Києво-Могилянська академія була одним із головних осередків навчання і практики партесного співу, виховуючи не лише співаків, регентів, а й майбутніх композиторів (багато 3 яких залишились невідомими, а їхні твори - анонімними). Осмислене навчання партесному співові й викладання риторики в провідних навчальних закладах - один із «факторів впливу» на взаємопроникнення риторики й музики в національному інваріанті барокової музики XVII століття. Однак «риторичність» української барокової музики також обумовлена тісними зв'язками 3 традиціями італійської, німецької та польської барокових шкіл.

Зв'язок музичного й риторичного мистецтва в бароковій музиці проявлений у таких аспектах звукового образу:

- «апріорній», визначальній ролі слова;

- декламаційності;

- емоційності вислову;

- ораторській інтонації;

- тяжінні до взаємодії зі слухачем;

- просторовості, «відкритості»;

- символічності;

- діалогічності (принцип «питання-відповідь»).

«Се есть ритор и се есть риторское учение. Несть бо риторики в мусикийском составлении, токмо учение четвертое гласовом исправление, своим чином идущее и грамматику имущее. И еже ю кто разумеет, тамо вся риторика в грамматице и философия, кто пети и пение сложити будет разумети» [10, с. 119], - так говорить І. Корєнєв, послідовник 
М. Дилецького, автор трактату «Мусикія» про зв’язок музичного й риторичного мистецтв, наголошуючи, що виконавець, який розуміє риторику, розумітиме й музику.

Інтенція слідувати за текстом притаманна композиторам, що звертаються до жанрів вокальної музики, адже текст - це своєрідна програма. Однак у мистецтві бароко ми спостерігаємо традицію слідування не змісту текстового джерела в цілому, а кожному слову як найменшому синтаксичному елементу. Далі наводимо фрагмент, що ілюструє форму такого слідування в партесній музиці.

Приклад № 1

Анонімний партесний конщерт «Господи, оружие крест твой» [3]
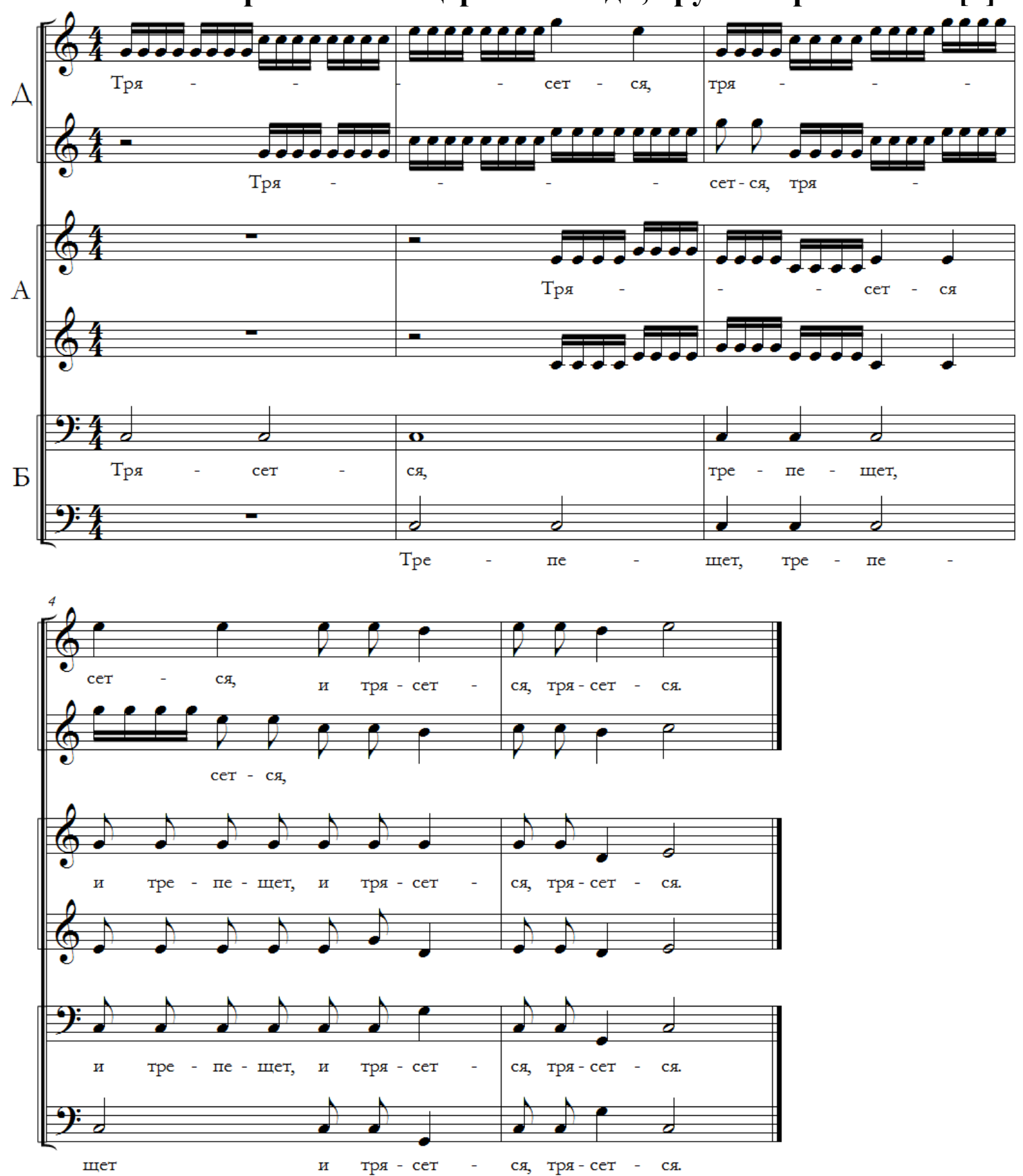
Наведений фрагмент показує пряме слідування слову: його ілюстративне відтворення реалізоване через багаторазове повторення звуку на тотожній висоті дрібними тривалостями - чітка візуалізація слова «трясеться». «Правило ествественное, по-латыни называемое натуральное, это то, когда композитор сочиняет в зависимости от смысла слов. Пусть будет текст “Сниде на землю”», - зазначає М. Дилецький у «Граматиці мусикійській» [6, с. 352].

У бароковій музиці слово $є$ «путівником» на рівні найменших синтаксичних структур - мотивів і фраз. Цей факт усвідомлюється при знайомстві з концертами й мотетами ліричного характеру. До стандартних музично-риторичних фігур, які часто можна зустріти в партесних творах, належать: anabasis - «вгору» і catabasis - «вниз», climax - «драбина» або gradatio - «посилення»; фігури suspiratio - «зітхання» або tmesis «розсікання». Дуже поширеними є фігури antitheton - «протиставлення», cadentia duriuscula, exclamatio - «вигук», hypotyposis - «зображення» та ін.

Символічне значення мають метричні контрасти. Н. О. ГерасимоваПерсидська пише: «Партесний концерт - це справді "musica poetica", він демонструє багато прикладів вживання музично-риторичних фігур. До того ж, слід вказати і на свої особливості: використовуються найбільш легко відчутні на слух, а не такі, що відносяться до музики “для зору”, розраховані на вчених знавців. У цьому виявилася сутність побутування жанру - твори виконувались у церквах, наповнених людьми 3 найширших верств населення. У той же час у партесному концерті були виявлені свої, особливі засоби розкриття тексту в музиці, які не можна вважати “риторичними фігурами". Радість і горе - мажор і мінор - мали кожен своє, досить вузьке коло постійних зворотів - мелодико-гармонічних, часто фактурних і ритмічних. Вони набули значення постійних епітетів $\mathrm{i}$ вказують на формування того, що пізніше називатимуть засобами виразності» ${ }^{2}$. Специфічність синтезу музики й риторики саме в українській українській бароковій музиці виявляється в більш простому, конкретному трактуванні слова, зменшенні тяжіння до абстрактних символів.

У трактаті «О музыке» вчений XVII століття Ю. Крижаніч пише: «Доний на странице семьдесят четыре порицает тех глупцов, которые сперва сочиняют мелодию, а потом подбирают к ней слова, ведь наслаждение доставляют не только сочетания звуков и музыкальный ритм, но услаждению души и возбуждению чувств способствуют, прежде всего, смысл слов затем складность речи, которая зависит от расстановки

\footnotetext{
${ }^{1}$ Герасимова-Персидская Н. Музыка Время Пространство. Київ : Дух і літера, 2012. С. 39.
} 
ударений в словах и от их звучания. Такой расстановки ударений и приятного звучания слогов не встречается во всем нашем славянском языке, но зато в нем полно сигматизмов и трескучих словосочетаний» [5, c. 402]. Ю. Крижаніч «декларує» важливість верховенства слова, необхідність досягнення контрасту через «колорування» кожного слова навіть у межах однієї фрази, однак із даної тези можна зробити висновок, що «звукова візуалізація» словесного матеріалу має, порівняно із західноєвропейським бароковим мистецтвом, більш вільну, розмиту форму. Вона спирається, найімовірніше, на частково засвоєну іноземну традицію, переосмислену в контексті слов'янського менталітету.

Цікавою стороною риторичності партесного співу $є$ його загальна спрямованість на слухача. М. Дилецький акцентує важливість розуміння й донесення словесного тексту до слухача, говорячи, що краще віддати текст читцю, ніж співати «без разума и без разумения» [6, с. 56]. Незважаючи на певну очевидність такої тези, донесення тексту під час хорового співу $є$ актуальною проблемою для будь-якого хорового колективу.

Таким чином, у трактаті «Мусикійська граматика» [6] ми можемо спостерігати досить часте акцентування уваги на важливості словесного в двох значеннях: загальному (відтворення базового сенсу текстового джерела) і локальному (ілюстративне відтворення кожного слова).

Однак у творах М. Дилецького часто спостерігаємо епізоди, в яких словесна логіка ігнорується: наприклад, наголошений склад припадає на синкопу - на четверту восьму в такті з розміром 4/4, до того ж у швидкому темпі. Очевидно, що в таких епізодах дотримання логічного наголосу досягти занадто складно - в умовах виконання, при вже встановленій ритмічній пульсації у швидкому темпі, збереження наголосу на цій долі такту призведе до втрати темпу. Крім того, викликає сумнів доцільність такої інтерпретації, оскільки, якби сам композитор вважав необхідним зберегти в даному епізоді словесний наголос, він знайшов би спосіб підтекстувати більш зручно, природно для виконання. Не дивлячись на відсутність тактових рис у нотаційній системі партесів, у рукописних джерелах є помітки - тактові риси, проставлені самими виконавцями для полегшення читання нотного тексту. Це свідчить про відчуття метру півчими, а тому виконання матеріалу без дотримання метричної логіки не можна вважати «правильним».

Сам М. Дилецький пише, що прийнятною формою композиції $\epsilon$ створення спочатку «фантазії», тобто музичного матеріалу, а потім підбирання до неї словесного тексту: «Правило бестекстовое, называемое по латыни “атексталис" это то, когда композитор задумывает музыку без текста, после же под ноты подставляет слова подходящие к задуманному» [6, с. 43]. 
У контексті такого підходу до створення партесів не виглядає дивним епізодичне неспівпадіння наголосів словесних і музичних структур - не тільки в моментах непомітних, де воно навряд чи буде зафіксоване слухом, а навіть у фінальних епізодах, кадансах, із багаторазовим повтором.

Приклад № 2

Фрагмент із «Воскресенського канону» М. Дилецького ${ }^{1}$
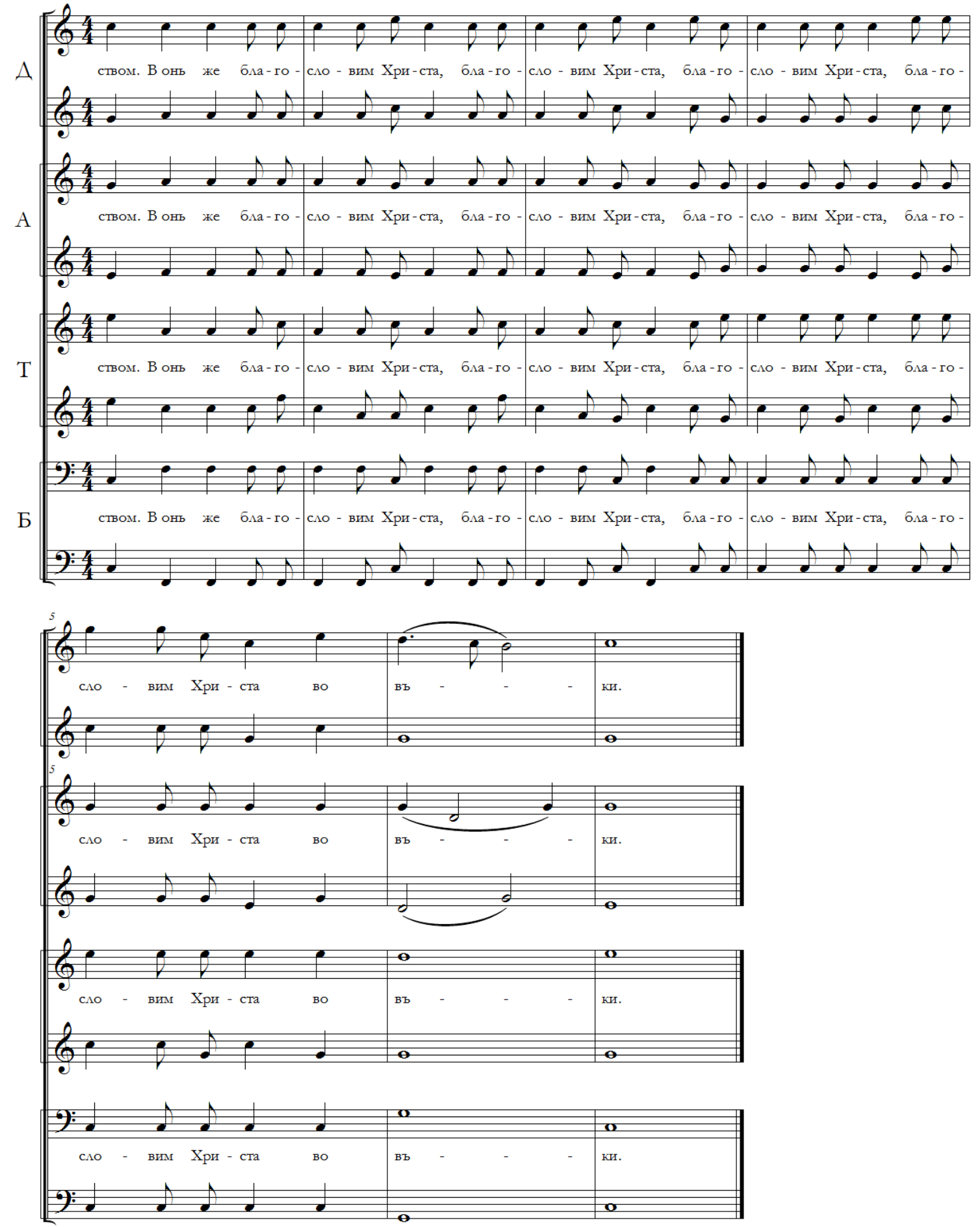

${ }^{1}$ Дилецький М. Хорові твори / упоряд., ред., вступ. ст. та комент. Н. О. ГерасимовоїПерсидської. Київ : Музична Україна, 1981. С. 69-70. 
Логічно було б зробити висновок, що поступово починається певний відхід від словесного домінування й початок розвитку усвідомлення музичного мистецтва як автономного пласту, 3 нейтралізацією повної залежності музичної думки від словесної.

Переходячи до аспекту реалізації звукового образу в практичній роботі через його риторичний компонент, ми використовуємо поняття «фразування» як загальнохоровий термін вибудови наголосів у синтаксичних структурах різної довжини. В партесних творах відсутні фрази романтичного типу - широкі, довгі, розраховані на ланцюгове дихання, однак виконавці часто тяжіють до їх відтворення. У такій формі проявлена «ораторська інтонація» - «інтонаційне фразування», притаманне партесам: пауза, акцентування або пом'якшення складу, пролонгація складу, багаторазове повторення, дискретність тощо - це своєрідна гра з увагою та сприйняттям слухача, форма інтерактиву. «У будові твору використані закони риторики - як у плануванні цілого, так i в зв'язках музики й слова 3 особливою увагою до ораторського жесту» 1 . Говорячи про приділення особливої уваги «ораторському жесту», імовірно, музикознавиця має на увазі чотири принципи ораторської жестикуляції, що втілюються в партесних творах як на рівні цілого, так i на рівні різних синтаксичних структур тексту: широта, відкритість, симетричність і завершеність жесту.

Драматургічний принцип «питання-відповідь» $\epsilon$ основним для партесного твору. Згаданий вище характер звукового образу реалізується за рахунок своєрідної діалогічності музичного тексту.

«Питання-відповідь» - універсальний метод донесення ідеї та зміни світогляду, що був відкритий Сократом («метод Сократа») як найбільш ефективний для досягнення ментального катарсису. Слухачі музичного твору «високого стилю» стають умовними «суб' єктами діалогу», музика орієнтована не на донесення церковних символів, а на створення особливого стану в слухачів: захоплення, радість, смуток. Не заглиблюючись в історичний аспект використання даної форми митцями добарокового періоду, зазначимо, що в XVII столітті велика кількість теоретиків в Україні писали музично-теоретичні праці саме за таким принципом. Сюди відносимо «Мусикію» І. Корєнєва та «Мусикійську граматику» М. Дилецького, трактат «Про музику» Ю. Крижаніча та ін.

\footnotetext{
${ }^{1}$ Герасимова-Персидская Н. Музыка. Время. Пространство. Київ : Дух і літера, 2012. С. 85.
} 
Отже, принцип реалізації архітектоніки твору через діалогічність $є$ важливим компонентом художнього тексту мистецьких артефактів у період українського бароко.

Даний принцип реалізується в тексті партесних творів через:

- співставлення та контрастування частин із різним метричним розміром;

- чергування повторних і неповторюваних текстових елементів;

- використання музичних «арок»;

- постійне контрастування двох типів фактури: поліфонічної та хоральної;

- використання поліфонічних прийомів;

- упорядковану взаємодію в рамках одного твору різнотембрових ансамблів;

- принцип концертування;

- принцип антифонності.

Останні два пункти найбільш зримо втілюють драматургічний принцип «питання-відповідь» і допомагають реалізувати ідею барокового твору через «завоювання» акустичного простору.

У своїй монографії [4] Н. О. Герасимова-Персидська зазначає, що в найбільш давніх поголосниках зустрічається позначка «Solo», однак авторка не вказує, до якого періоду побутуванння партесів відносяться дані рукописи. Якщо врахувати традиційний склад барокового ансамблю (13-15 співаків), протиставлення solo - tutti може видаватись недоречним, адже виконавці співають камерним складом, де кожен є солістом. Однак, для періоду XVII століття навіть такий контраст може суттєво змінювати акустичний ефект, а отже, звуковий образ.

Повертаючись до питання звукового образу партесного твору, важливо зрозуміти його характер та ступінь і міру реалізації зазначених вище риторичних аспектів.

«Протягом XVII ст. ікона поступово втрачає значення певного ієратично-містичного й абстрактного, далекого від життя символу, набуваючи рис реалістичного, сповненого гуманізму зображення. Урочиста умовність строго площинної композиції 3 ритмічним чергуванням форм, ліній і кольорових площин та більш або менш чітко вираженими елементами графічності поступається живописно-об'ємному трактуванню образів у плані звичайної картини з конкретними рисами сучасників у типажі та побутової обстановки в одязі, інтер’єрі, пейзажі. По суті, на релігійний характер багатьох творів вказують тільки німби»,такий опис дає В. Свінцицька українській бароковій іконі, умовно описуючи будь-який художній об'єкт періоду українського бароко. Дана вербалізація, насамперед, закарбовує характер твору даного періоду, зміну 
художньої парадигми через виведення на перший план не символічного змісту (що традиційно для ортодоксальної культури даного часу), а художнього образу. Звуковий образ характеризується відкритістю, контрастністю, рельєфністю звукового втілення, стає орієнтованим на слухача та, у певному сенсі, втрачає молитовність. Іван Вишенський описує даний образ як «страсті вавилонські», даючи в даному коментарі посилання на характер виконання, описує як сприймали слухачі звуковий образ партесного твору.

Отже, «рушійною силою» у створенні й інтерпретації партесного твору є слово в загальному та більш конкретному розумінні. Однак даний алгоритм (слідування слову) не $є$ універсальним для всього періоду українського бароко, він трансформується, видозмінюється під впливом індивідуального бачення композиторів, а також через зближення 3 інструментальним мистецтвом і прийняття віянь епохи класицизму. В українській бароковій музиці ми спостерігаємо специфічні форми взаємодії риторичного й музичного мистецтва як на рівні окремих епізодів, так і на рівні архітектоніки цілого твору, що виявляються в «апріорній», визначальній ролі слова, декламаційності, емоційності вислову, ораторській інтонації, прагненні взаємодії зі слухачем, просторовості, «відкритості», символічності, діалогічності (принцип «питаннявідповідь»), ідентифікація та реалізація яких наближає виконавця до втілення історично-достовірного звукового образу.

1. Арнонкур Н. Музика як мова звуків : науково популярне видання. Суми : Собор, $2002.184 \mathrm{c}$.

2. Герасимова-Персидская Н. ... и слово в музыку вернись // Науковий вісник НМАУ ім. П. І. Чайковського. Вип. 38 : Муз. стиль: теорія, історія, сучасність. Київ, 2004. C. 3-8.

3. Герасимова-Персидская Н. Українські партесні мотети початку XVIII століття. Київ : Музична Україна, 1991. 359 с.

4. Герасимова-Персидська Н. Хоровий концерт на Україні в XVII-XVIII столітті. Київ : Музична Україна, 1978. 180 с.

5. Гольдберг А., Аввакумов Ю., Белоненко А., Карцовник В. Трактат о музыке Юрия Крижанича // Труды Отдела древнерусской литературы. Ленинград: Наука. Ленингр. отд-ние, 1985. Т. XXXVIII. С. 356-410.

6. Дилецкий Н. Идеа грамматики Мусикийской / публикации, перевод, исследование и комментарии В. Протопопова. Москва : Музыка, 1979. 636 с.

7. Ігнатенко С. В. «Високий стиль» хорового концерту кінця XVII-XVIII ст.: до проблеми музично-поетичної цілісності : автореф. дис. ... канд. мистецтвознавства : 17.00.03 / НМАУ ім. П. І. Чайковського. Київ, 2005. 19 с. 
8. Кузьмінський I. Витоки, музична теорія та виконавська практика партесного багатоголосся : дис. ... канд. мистецтвознавства : 17.00.03 / НМАУ ім. П. І. Чайковського. Київ, 2014. 171 с.

9. Медведик Ю. Українська духовнопісенна творчість XVII-XVIII ст.: джерела, текстологія та жанрова стилістика: автореф. дис. ... д-ра мистецтвознавства: 17.00.03 / НМАУ ім. П. І. Чайковського. Київ, 2009. 44 с.

10. Музыкальная эстетика России XI-XVIII веков/ сост. текстов, пер. и общ. вступ. статья А. И. Рогова. Москва : Музыка, 1973. 244 с.

11. Свінцицька В. Іван Руткович і становлення реалізму українського малярства XVII століття. Київ : Наукова думка, 1966. 174 с.

12. Стельмащук Р. Барокові музично-риторичні фігури в українській музиці партесного стилю: тенденції, закономірності, особливості // Молодь і ринок. 2011. № 10. С. 100-104.

13. Шуміліна О. Стильова динаміка української духовної музики XVII-XVIII століть (за матеріалами рукописних колекцій) : монографія / Нац. муз. акад. України ім. П. І. Чайковського. Донецьк, 2012. 299 с.

\section{References}

1. Harnoncourt, N. (2002). Music as a language of sounds. Sumy: Sobor [in Ukrainian].

2. Herasymova-Persydskaia, N. (2004). ... and the word to the music come back. Naukovyi visnyk NMAU im. P. I. Chaikovskoho, 38, pp. 3-8 [in Russian].

3. Herasymova-Persydska, N. (1991). Ukrainian baroque motets of the early XVIIIth century. Kyiv: Muzychna Ukraina [in Ukrainian].

4. Herasymova-Persydska, N. (1978). Choir concert in Ukraine in the XVII-XVIII centuries. Kyiv: Muzychna Ukraina [in Ukrainian].

5. Goldberg, A., Avvakumov, J., Belonenko, A., Karcovnik, V. (1984). Treatise about music of Yuri Krizhanich. Trudy Otdela drevnerusskoy literatury, 38, pp. 356-409 [in Russian].

6. Dyletskyi, N. (1979). The idea of the Music grammar. V. Protopopov (Ed.). Moscow: Muzyka [in Russian].

7. Ihnatenko, Y. (2005). "High style» of the choral concert of the end of XVII and XVIII centuries: to the problem of musical and poetic integrity. Extended abstract of $\mathrm{PhD}$ thesis. Ukrainian National Tchaikovsky Academy of Music. Kyiv [in Ukrainian].

8. Kuzminskii, I. (2014). Origins, musical theory and performing practice of partes polyphony. $\mathrm{PhD}$ thesis. Ukrainian National Tchaikovsky Academy of Music. Kyiv [in Ukrainian].

9. Medvedyk, Y. (2005). Ukrainian spiritual art of the XVII-XVIII centuries: sources, textology and genre stylistics. Extended abstract of D.Sc. thesis. Ukrainian National Tchaikovsky Academy of Music. Kyiv [in Ukrainian].

10. Rogov, A. (Ed.) (1973). Musical aesthetics of Russia in XI-XVIII centuries. Moscow: Muzyka [in Russian].

11. Svintsytska, V. (1966). Ivan Rutkovich and the formation of the realism of Ukrainian painting of the XVII century. Kyiv: Naukova dumka [in Ukrainian].

12. Stelmashchuk, R. (2011). Baroque musical-rhetorical figures in Ukrainian music of partes style: tendencies, patterns, peculiarities. Molod i rynok, 10(81), pp. 100-104 [in Ukrainian].

13. Shumilina, O. (2012). Style dynamics of Ukrainian spiritual music of XVIIXVIII centuries (based on manuscript collections). Donetsk [in Ukrainian]. 